\title{
Influence of Temperature and Salinity Stress on Seed Germination and Seedling Growth of Soybean (Glycine max L.)
}

\author{
Mustafa Çirka ${ }^{1}$, Ali Rahmi Kaya ${ }^{2}$, Tamer Eryiğit ${ }^{3}$
}

10.18805/LR-628

\begin{abstract}
Background: The high salt level of a germinating environment can lead to reduced, delayed, and even complete inhibition of germination and seeding growth due to osmotic action and/or ion toxicity. Based on this viewpoint, the aim of this study was to investigate germination temperature and salinity effects on germination and early seedling growth of soybean, which can be sown as first and second crops.

Methods: Soybean seeds were subjected to $\mathrm{NaCl}$ induced saline germinating media prepared in petri dishes under two different germination temperatures $\left(20 \pm 2\right.$ and $\left.25 \pm 2^{\circ} \mathrm{C}\right)$. Thirty sterilized seeds per petri dish were sown in ten salt treatments $(0,100,150$, $250,750,1000,2250,5000,7500$ and $10000 \mathrm{ppm} \mathrm{NaCl} \mathrm{L}^{-1}$ ). The study was carried out according to the completely randomized design with four replications.

Result: Lower temperature promoted seed germination, while the high temperature significantly inhibited the seed germination at all $\mathrm{NaCl}$ doses tested. As a result, $25^{\circ} \mathrm{C}$ temperatures, which can only be measured at the time of the second sowing, have been found to negatively affect germination and also increase the negative effects of salt. Due to the moderate tolerance of soybeans to salt

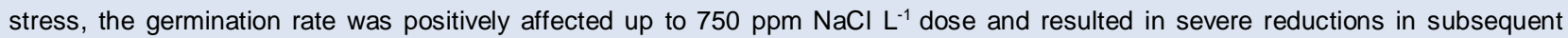
doses. Also, the tolerance of soybean was negatively influenced by the interaction of temperature and $\mathrm{NaCl}$ concentration.
\end{abstract}

Key words: Germination, Salinity, Seedling vigor index, Soybean, Temperature.

\section{INTRODUCTION}

Biotic or abiotic agents that negatively affect the growth and development of plants in normal living environments are evaluated as stress factors. The two essential environmental factors that currently reduce plant productivity in common are drought and salinity (Jamil et al. 2006).

Salinity is a major abiotic stress factor that reduces plant productivity on both irrigated and non-irrigated agricultural lands especially in semi-arid, arid countries and throughout the world (Chaitanya et al. 2014). Most of the world's soils are not cultivated, but a significant portion of the cropland is affected by salt. Over $7 \%$ of the world's land is affected by either sodicity or salinity (Mahmood et al. 2010). According to The Food and Agriculture Organization of the United Nations, of the existing world agricultural land, 45 million ha $(19.5 \%)$ of the irrigated agricultural area of 230 million ha and 32 million (2.1\%) ha of the dry agricultural area of 1.500 million ha are affected by salt. Soil salinity is the main reason that the plant-water economy is hampered. The plant uses more energy and consumes less water during periods when the concentration of salt in the root zone remains. This results in a loss of yield and quality in terms of plant production. There is a need for hardy plant species and varieties to reduce these losses in salty soils (Altuner et al. 2020). As is known, some plants are moderately tolerant of saline conditions, while many plants are negatively affected by even low salt levels. Salinity negatively affects plant growth and productivity at all stages of development (Miladinov et al. 2020).

Seed germination is a first and very important stage in the life cycle of plants. Germination is one of the most vital
Department of Field Crops, Agricultural Faculty, Kahramanmaras Sutcu Imam University, 46000, Kahramanmaraş, Turkey.

${ }^{1}$ Department of Field Crops, Agricultural Faculty, Van Yuzuncu Yil University, Turkey.

${ }^{2}$ Department of Field Crops, Agricultural Faculty, Kahramanmaraş Sutcu Imam University, Turkey.

${ }^{3}$ Department of Plant and Animal Production, Gevas Vocational School, Van Yuzuncu Yil University, Turkey.

Corresponding Author: Tamer Eryiğit, Department of Plant and Animal Production, Gevas Vocational School, Van Yuzuncu Yil University, Turkey. Email: tamyigit@hotmail.com

How to cite this article: Çirka, M., Kaya, A.R. and Eryiğit, T. (2021). Influence of Temperature and Salinity Stress on Seed Germination and Seedling Growth of Soybean (Glycine max L.). Legume Research. 44(9): 1053-1059. DOI: 10.18805/LR-628.

Submitted: 29-04-2021 Accepted: 05-06-2021 Online: 03-08-2021

periods for a product exposed to salinity (Dutta and Bera, 2014). Salinity effects seed germination via external osmotic production which prevents water absorption and $\mathrm{Na}^{+}$and $\mathrm{Cl}^{-}$ions' toxic effects (Turhan and Ayaz, 2004). Therefore, the salt tolerance of seeds during germination is critical for plants to grow in saline soils (Khan et al. 2000). Furthermore, it is known that in the germination and development of many plants, higher temperature interacts with salinity and increases the effect of stress conditions (Nedjimi, 2013). So, in cases where the salinity problem in the soil cannot be solved in the short term, the most basic approach to be followed is to identify salt-resistant species (Oral et al. 2019). 
Soybean is a product of high agricultural value whose cultivation and production are limited by salinity, one of the abiotic environmental stress factors (Ramana et al. 2012), has a relatively wide variation in salt tolerance among its genotypes (Wang and Shannon, 1999). Therefore, soybean species is classified as moderately salt-tolerant plants and soybean yield decreases when the soil salinity exceeds $5 \mathrm{ds} /$ $\mathrm{m}$ (Ashraf and Wu, 1994). Soybean species show a range of salt tolerance capability (Phang et al. 2008), but high salt damages the entire life cycle of soybeans. The degree of salt tolerance varies among the different stages of soybean species' development. The seedling stage of soybeans is considered more susceptible to salt stress than the germination stage (Hosseini et al. 2002). The germination of soybean seeds was delayed in low salt $(0.05 \%$ and $0.1 \%$ $\mathrm{NaCl}$ ) conditions (Phang et al. 2008). Additionally, salinity influences germination rate, germination percentage, and seedling growth in diverse ways depending on species of plants (Jamil and Rha, 2004). One of the factors affecting germination for plants planted as the first and second crop is the germination temperature. High temperature speeds up the movement of molecules, causing the bonds between large organic molecules to loosen and the biological membranes to become more fluid. Therefore, high temperatures increase the passage of salt minerals through the flexible cell membrane, resulting in greater penetration of salt into plant cells. The salinity level above the salinity tolerance of plants disrupts seed germination, reduces nodule formation, delays plant development and reduces crop yield. Given the information presented above, an investigation was carried out to determine the influences of temperature and salinity stress on the germination and seedling growth parameters of Glycine max L.

\section{MATERIALS AND METHODS}

The study was conducted under the uniform condition in the library of the Department of Field Crops, Kahramanmaras Sutcu Imam University, Turkey, in 2016. The uniform-sized seeds of Gapsoy soybean (Glycine max L.) cultivar were used as a material in this study. After their surfaces were sterilized with $5 \% \mathrm{NaOCl}$ (sodium hypochlorite) solution for five minutes and rinsed in tap water, 30 soybean seeds were left to germinate under two different germination temperatures $\left(20 \pm 2\right.$ and $\left.25 \pm 2^{\circ} \mathrm{C}\right)$. In closed, sterilized Petri dishes, each with two Whatman filter papers were soaked with $15 \mathrm{ml}$ of different salt concentrations (TDS (Total Dissolved Solids in water): 0, 100, 150, 250, 750, 1000, 2250, 5000, 7500 and 10000 ppm NaCl L-1). The seeds were considered germinated by the emergence of the radicle. The seeds were allowed to maintain the germination in each replicate for measurements of radicle and hypocotyls lengths at the end of the experiment. After 14 days germinated seeds were taken out from the petri dishes, final germination percentages and some other basic germination and seedling growth properties such as germination index, radicle length, plumule length, seedling length, radicle fresh weight, plumule fresh weight, seedling fresh weight, radicle dry weight, plumule dry weight, seedling dry weight and seedling vigor index were determined.

The germination percentage and germination index were calculated by the following formulas:

Germination percentage $(\mathrm{GP})=$

$$
\frac{\text { Number of germinated seeds }}{\text { Total number of seeds }} \times 100
$$

The germination index was calculated after the $14^{\text {th }}$ day of germination by the following equation (Karim et al. 1992).

Germination Index (GI) =

$$
\frac{\text { Germination \% in each treatment }}{\text { Germination \% in the control }} \times 100
$$

Seedling vigor index $=$

Seedling lengh $(\mathrm{cm}) \times$ Germination percentage \%

(Rathi and Madan, 2019)

The seedling length was measured with a ruler. Similarly, the length of the radicle and plumule were measured with a measuring band after both separated. Then, these two pieces weighed to determine fresh weight. The germinated seeds' samples were kept at $70^{\circ} \mathrm{C}$ for 24 hours for weighing to achieve seedling dry weight (Moosavi et al. 2014). The seedling vigor index was obtained by multiplying the seedling length by the germination percentage.

\section{Statistical analysis}

The statistical analysis for the investigated treatment factors, temperatures and $\mathrm{NaCl}$ concentrations, were carried out by using SAS statistical software one-way analysis of variance (Anova) according to the completely randomized experimental design procedures. Least significant difference (LSD) analysis was performed from Post hoc multiple comparison tests to screen the differences among the levels of $\mathrm{NaCl}$ interacted with both germination temperatures in each studied parameter at the $5 \%$ significance level. Additionally, the Pearson Correlation analysis was performed to evaluate the relationships among the observed parameters.

\section{RESULTS AND DISCUSSION}

The data obtained as a result of applications of different germination temperatures and salinity levels to the soybean seeds are shown in Tables 1 and 2. The simple scatter plot matrices between seedling vigor index and other studied features are monitored in Fig $1 \mathrm{~A}-\mathrm{H}$.

\section{Germination percentage}

The results showed that the germination temperatures had a significant $(5 \%)$ effect on the germination percentage. Germination percentages obtained from different temperature environments were determined as $41.3 \%$ (GT1) to $42.5 \%$ (GT2) in Table 1. In terms of its effect on germination percentage, there were statistically very significant $(1 \%)$ differences among salinity levels and the common effects of the factors. The highest germination percentage (70.0\%) 


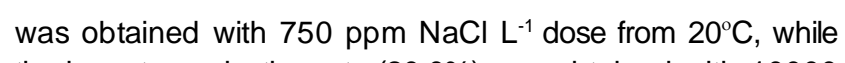
the lowest germination rate $(20.0 \%)$ was obtained with 10000 ppm $\mathrm{NaCl} \mathrm{L}{ }^{-1}$ dose from $25^{\circ} \mathrm{C}$ (Table 1).

\section{Germination index}

As seen in Table 1, it was observed that there were statistically very significant $(1 \%)$ difference between the temperatures in terms of germination indices. The highest germination index (3.59) was determined under $20^{\circ} \mathrm{C}$, while the lowest (2.98) was calculated under $25^{\circ} \mathrm{C}$. In Table 1 , it was determined that there were statistically very significant $(1 \%)$ variations among the salinity levels and effects of the interactions of the factors on the germination index. The highest germination indices (5.43 and 5.18) were determined under both temperatures' applications from 750 and $250 \mathrm{ppm} \mathrm{NaCl} \mathrm{L}^{-1}$ while the lowest (1.43) was found in $25^{\circ} \mathrm{C}$ from $10000 \mathrm{ppm}$ $\mathrm{NaCl} \mathrm{L} L^{-1}$ (Table 1).

\section{Radicle length}

As a result of the variance analysis of the radicle lengths, it was seen that there was a significant $(1 \%)$ statistical difference between the temperatures applied. While it was observed that the highest radicle length $(1.62 \mathrm{~cm})$ was measured under $20^{\circ} \mathrm{C}$, the lowest value $(1.36 \mathrm{~cm})$ was obtained from $25^{\circ} \mathrm{C}$ treatment (Table 1$)$. Statistically (1\%) significant variations were found among the salinity levels and common effects of both factors on radicle lengths. The highest radicle length $(2.63 \mathrm{~cm})$ was seen at $20^{\circ} \mathrm{C}$ from the fifth dose of salinity, while the lowest radicle length $(0.24 \mathrm{~cm})$ was measured at the tenth dose from $25^{\circ} \mathrm{C}$ temperature (Table 1). Plumule length

When plumule lengths are examined in Table 1, it is seen that there are statistically significant differences between the

Table 1: The means and the LSD groups of GP, GI, RL, PL, SL, RFW properties of soybean variety (Gapsoy).

\begin{tabular}{|c|c|c|c|c|c|c|c|c|c|c|c|c|c|}
\hline $\begin{array}{l}\text { Germination } \\
\text { temperature }\left({ }^{\circ} \mathrm{C}\right)\end{array}$ & $\begin{array}{c}\text { Salt } \\
\text { doses }(\mathrm{ppm})\end{array}$ & $\begin{array}{l}\text { GP } \\
(\%)\end{array}$ & ${ }^{* ; * *}$ & GI & *;** & $\begin{array}{c}\mathrm{RL} \\
(\mathrm{cm})\end{array}$ & $* ; * *$ & $\begin{array}{c}\mathrm{PL} \\
(\mathrm{cm})\end{array}$ & $* ; * *$ & $\begin{array}{l}\mathrm{SL} \\
(\mathrm{cm})\end{array}$ & *;** & $\begin{array}{l}\text { RFW } \\
(\mathrm{g})\end{array}$ & $* ; * *$ \\
\hline \multirow{11}{*}{ GT1 } & SD1 & 40.0 & $e-h$ & 2.92 & $\mathrm{fg}$ & 1.65 & $f$ & 5.70 & de & 7.35 & $\mathrm{~cd}$ & 26.4 & $\mathrm{~cd}$ \\
\hline & SD2 & 41.0 & $e-g$ & 4.08 & $d$ & 2.13 & $d$ & 4.46 & $\mathrm{~h}$ & 6.59 & $\mathrm{e}$ & 23.9 & de \\
\hline & SD3 & 46.0 & $\mathrm{De}$ & 4.83 & $b$ & 1.94 & e & 6.75 & $b$ & 8.69 & $b$ & 26.5 & c \\
\hline & SD4 & 51.0 & $\mathrm{bc}$ & 4.44 & $c$ & 1.68 & $f$ & 5.30 & $f$ & 6.97 & $d$ & 26.5 & $c$ \\
\hline & SD5 & 70.0 & $a$ & 5.43 & $\mathrm{a}$ & 2.63 & $a$ & 7.13 & a & 9.76 & $\mathrm{a}$ & 49.4 & a \\
\hline & SD6 & 49.0 & $\mathrm{~cd}$ & 3.09 & $f$ & 1.38 & $g$ & 5.99 & $d$ & 7.37 & $d$ & 29.4 & $b$ \\
\hline & SD7 & 41.0 & $e-g$ & 2.96 & $f$ & 1.23 & $\mathrm{i}$ & 5.63 & e & 7.33 & $d$ & 29.1 & $b$ \\
\hline & SD8 & 34.0 & $\mathrm{i}$ & 4.06 & $d$ & 1.70 & $f$ & 4.06 & $\mathrm{i}$ & 5.28 & $\mathrm{~g}$ & 21.7 & $f$ \\
\hline & SD9 & 28.0 & j & 2.06 & $\mathrm{jk}$ & 0.86 & $\mathrm{k}$ & 3.94 & j & 4.91 & $\mathrm{~h}$ & 18.4 & $g$ \\
\hline & SD10 & 25.0 & $\mathrm{k}$ & 2.01 & $\mathrm{k}$ & 0.98 & j & 3.93 & $\mathrm{j}$ & 4.80 & $\mathrm{~h}$ & 14.7 & $\mathrm{~h}$ \\
\hline & Average & 42.5 & A & 3.59 & A & 1.62 & A & 5.29 & A & 6.91 & A & 26.6 & A \\
\hline \multirow{11}{*}{ GT2 } & SD1 & 37.0 & $f-i$ & 3.15 & $f$ & 0.87 & jk & 3.68 & j & 4.55 & $\mathrm{~h}$ & 22.2 & ef \\
\hline & SD2 & 36.0 & $g-i$ & 2.52 & hi & 1.56 & $f$ & 4.70 & gh & 6.26 & ef & 14.9 & $\mathrm{~h}$ \\
\hline & SD3 & 37.0 & $g-i$ & 2.67 & gh & 1.35 & $\mathrm{~h}$ & 4.99 & g & 6.34 & ef & 22.6 & ef \\
\hline & SD4 & 67.5 & $a$ & 5.18 & $a$ & 2.45 & $b$ & 6.26 & c & 7.71 & $c$ & 29.2 & $b$ \\
\hline & SD5 & 54.0 & $b$ & 3.77 & $\mathrm{e}$ & 2.36 & c & 4.21 & $\mathrm{i}$ & 6.57 & $\mathrm{e}$ & 24.1 & de \\
\hline & SD6 & 52.0 & $\mathrm{bc}$ & 3.67 & $\mathrm{e}$ & 1.89 & e & 4.09 & $\mathrm{i}$ & 5.98 & $f$ & 25.8 & $\mathrm{~cd}$ \\
\hline & SD7 & 42.0 & ef & 2.87 & $\mathrm{fg}$ & 1.33 & $\mathrm{~h}$ & 3.96 & ij & 4.93 & $\mathrm{~h}$ & 14.9 & $\mathrm{~h}$ \\
\hline & SD8 & 35.0 & hi & 2.37 & $\mathrm{i}$ & 0.97 & j & 2.41 & $\mathrm{k}$ & 3.74 & $\mathrm{i}$ & 11.1 & $\mathrm{i}$ \\
\hline & SD9 & 32.0 & $\mathrm{i}$ & 2.22 & j & 0.56 & I & 1.31 & I & 1.87 & j & 11.0 & $\mathrm{i}$ \\
\hline & SD10 & 20.0 & I & 1.43 & I & 0.24 & $\mathrm{~m}$ & 1.09 & $\mathrm{~m}$ & 1.32 & $\mathrm{k}$ & 6.9 & j \\
\hline & Average & 41.3 & B & 2.98 & B & 1.36 & B & 3.67 & B & 4.93 & B & 18.3 & B \\
\hline LSD (5\%) for GT & & 1.258 & * & 0.072 & $* *$ & 0.031 & ** & 0.079 & ** & 0.085 & $\star \star *$ & 0.466 & $* *$ \\
\hline LSD (5\%) for SD & & 2.814 & $* *$ & 0.161 & $* *$ & 0.069 & ** & 0.177 & ** & 0.190 & $* *$ & 1.041 & $* *$ \\
\hline $\operatorname{LSD}(5 \%)$ for $\mathrm{GT} \times \mathrm{SD}$ & & 7.959 & $* *$ & 0.456 & $* *$ & 0.194 & ** & 0.501 & ** & 0.538 & $* *$ & 2.944 & $* *$ \\
\hline CV (\%) & & 6.719 & & 4.906 & & 4.607 & & 3.956 & & 3.211 & & 4.635 & \\
\hline
\end{tabular}

GP: Germination percentage, Gl: Gemination index, RL: Radicle length, PL: Plumule length, SL: Seedling length, RFW: Radicle fresh weight; GT1: $20^{\circ} \mathrm{C}$, GT2: $25^{\circ} \mathrm{C}$, Salt doses (SD1: Control, SD2: 100 ppm NaCl L-1 SD3: 150 ppm NaCl L-1, SD4: 250 ppm NaCl L-1, SD5:750 ppm NaCl L-1, SD6: 1000 ppm NaCl L-1, SD7: 2250 ppm NaCl L-1, SD8: 5000 ppm NaCl L-1, SD9: 7500 ppm NaCl L-1, SD10: 10000 ppm $\mathrm{NaCl} \mathrm{L}{ }^{-1}$ ).

*: The means in the same column, expressed in lowercase and indicated with different letters, are statistically different from each other within the $\mathrm{P}<0.05$ error limits according to Duncan's test.

${ }^{* *}$ : The means in the same column, expressed in the capital and indicated with different letters, are statistically different from each other within the $\mathrm{P}<0.05$ error limits according to LSD test. 
applied temperatures (1\%). The highest plumule length was measured as $5.29 \mathrm{~cm}$ from $20^{\circ} \mathrm{C}$ temperature treatment. There were statistically significant (1\%) differences between salinity levels and the effects of interactions of factors on plumule lengths. The highest plumule length was seen in the fifth dose of salinity at $20^{\circ} \mathrm{C}$, while the lowest $(7.13 \mathrm{~cm})$ was observed in tenth salinity levels as $1.09 \mathrm{~cm}$ at $25^{\circ} \mathrm{C}$ (Table 1).

\section{Seedling length}

As seen in Table 1, it is seen that there is a statistically very significant difference (1\%) between the temperatures' conditions in terms of seedling lengths. The highest seedling length was measured from $20^{\circ} \mathrm{C}$ temperature application $6.91 \mathrm{~cm}$, while the lowest value was determined for $25^{\circ} \mathrm{C}$ as $4.93 \mathrm{~cm}$ (Table 1). When the effect of salinity levels and common effects of both factors on seedling lengths are examined from Table 1 , it is seen that there are statistically significant variations (1\%) among salt doses and the interaction of both factors. The highest seedling length was measured as 9.76 $\mathrm{cm}$ from the fifth level of salinity at $20^{\circ} \mathrm{C}$ temperature, while the lowest value was observed as $1.32 \mathrm{~cm}$ from the tenth salt dose at $25^{\circ} \mathrm{C}$ (Table 1 ).

\section{Radicle fresh weight}

When the average fresh weights of the radicles are examined from Table 1, it is seen that there is a significant difference (1\%) between the temperature applications. The maximum radicle fresh weight $(26.6 \mathrm{~g})$ was determined at $20^{\circ} \mathrm{C}$ temperature, while the lowest value $(18.3 \mathrm{~g})$ was observed under the $25^{\circ} \mathrm{C}$ temperature condition. In Table 1, it can be observed that there are statistically significant $(1 \%)$ differences among the salt doses and interaction effects of the factors on the radicle fresh weights. The highest radicle fresh weight $(49.4 \mathrm{~g})$ was seen in the treatment of the fifth salt dose, while the lowest value $(6.9 \mathrm{~g})$ was seen in the tenth treatment (Table 1).

\section{Plumule fresh weight}

As a result of the variance analysis of the plumule fresh weight, it was seen that there was a significant (1\%) statistical difference between the temperatures' conditions. While it was observed that the highest plumule fresh weight $(436.7 \mathrm{~g})$ was measured at $20^{\circ} \mathrm{C}$, the lowest value $(386.7 \mathrm{~g})$ was weighed from the $25^{\circ} \mathrm{C}$ treatment (Table 2). Statistically $(1 \%)$ significant differences were found among the salinity levels and common effects of both factors on the plumule fresh weight. The highest plumule fresh weight $(562.3 \mathrm{~g})$ was seen at $20^{\circ} \mathrm{C}$ from the fifth level of salinity, while the lowest plumule fresh weights $(236.2$ and $236.5 \mathrm{~g})$ were measured at the tenth dose of salt application at 20 and $25^{\circ} \mathrm{C}$ temperatures (Table 2 ).

\section{Seedling fresh weight}

As seen in Table 2, it can be determined that there is a statistically very significant difference $(1 \%)$ between the conditions of temperatures in terms of the seedling fresh weight. The highest seedling fresh weight was determined from $20^{\circ} \mathrm{C}$ temperature application as $489.8 \mathrm{~g}$, while the lowest value was determined for $25^{\circ} \mathrm{C}$ as $405.0 \mathrm{~g}$ (Table 2). When the effect of salinity levels and common effects of both factors on the seedling fresh weight are examined from Table 2, it is seen that there are statistically significant variations (1\%) among salinity levels and the interaction effects of both factors. The highest seedling fresh weight was measured as $591.4 \mathrm{~g}$ from the fifth level of salinity at $20^{\circ} \mathrm{C}$ temperature, while the lowest values were observed as $(250.9$ and $247.6 \mathrm{~g})$ from the tenth salt doses at both temperature treatments (Table 2).

\section{Radicle dry weight}

When the average dry weights of the radicles are examined from Table 2, it is seen that there is a significant difference (1\%) between the temperature treatments. The maximum radicle dry weight $(4.9 \mathrm{~g})$ was observed at $20^{\circ} \mathrm{C}$ temperature, while the lowest value $(3.8 \mathrm{~g})$ was seen under $25^{\circ} \mathrm{C}$ temperature conditions. In Table 2, it can be observed that there are statistically significant $(1 \%)$ differences among the salinity levels and interaction effects of the factors on the radicle dry weights. The highest radicle dry weight $(7.4 \mathrm{~g})$ was seen in the treatment of the fifth salt dose, while the lowest value $(1.8 \mathrm{~g})$ was seen in the tenth treatment at $25^{\circ} \mathrm{C}$ (Table 2).

\section{Plumule dry weight}

As a result of the variance analysis of the plumule dry weight, it was seen that there was a significant $(1 \%)$ statistical difference between the effects of the temperatures. While it was observed that the highest plumule dry weight $(86.5 \mathrm{~g})$ was observed at $20^{\circ} \mathrm{C}$, the lowest value $(81.3 \mathrm{~g})$ was weighed from the $25^{\circ} \mathrm{C}$ treatment (Table 2). Statistically (1\%) significant differences were found among the salt doses and common effects of both factors on the plumule dry weight. The highest plumule dry weight $(99.9 \mathrm{~g})$ was seen at $20^{\circ} \mathrm{C}$ from the fifth dose of salt, while the lowest plumule fresh weights (48.9 and $50.2 \mathrm{~g}$ ) were measured at the tenth salinity levels at $20^{\circ} \mathrm{C}$ and $25^{\circ} \mathrm{C}$ temperatures (Table 2).

\section{Seedling dry weight}

As seen in Table 2, it can be determined that there is a statistically very significant difference $(1 \%)$ between the effects of the temperatures in terms of the seedling dry weight. The highest seedling dry weight was determined from $20^{\circ} \mathrm{C}$ temperature application as 91.8 , while the lowest value was determined for $25^{\circ} \mathrm{C}$ as $84.9 \mathrm{~g}$ (Table 2). When the effect of salinity levels and common effects of both factors on the seedling dry weight are examined from Table 2, it can be observed that there are statistically significant differences (1\%) among salt doses and the interaction effects of both factors. The highest seedling dry weight was measured as $105.1 \mathrm{~g}$ from the fifth level of salinity at $20^{\circ} \mathrm{C}$ temperature, while the lowest values were observed as $(52.0$ and $52.5 \mathrm{~g}$ ) from the tenth salinity levels at the both temperatures treatments (Table 2).

\section{Seedling vigor index}

As shown in Table 2, it can be determined that there is a statistically very significant difference $(1 \%)$ between the 
temperature treatments in terms of the seedling vigor index. The highest seedling vigor index was observed from the $20^{\circ} \mathrm{C}$ temperature treatment as $316.3 \mathrm{~g}$, while the lowest value was determined for $25^{\circ} \mathrm{C}$ temperature as $234.2 \mathrm{~g}$ (Table 2). When the effect of salinity levels and common effects of both factors on the seedling vigor index are examined from Table 2, it is seen that there are statistically significant variations (1\%) among salinity levels and the interaction effects of both factors. The highest seedling vigor indices were calculated as 663.5 and $653.3 \mathrm{~g}$ from the fifth level of salinity at $20^{\circ} \mathrm{C}$ temperature and fourth level at $25^{\circ} \mathrm{C}$, while the lowest value was determined as $(26.5 \mathrm{~g})$ from the tenth salinity level at $25^{\circ} \mathrm{C}$ temperature treatment (Table 2).

\section{The correlation among the investigated parameters}

A correlation analysis was performed to accurately identify the relationships between all the studied properties of soybeans. Correlations between most of the parameters studied were found to be significant (1\%) due to interactions from different temperatures and salt doses. The simple scatter plot and curves of correlation matrices between seedling vigor index and other studied properties were presented in Fig 1. As can be seen from Fig 1, it is observed that there are generally positive interactions among all the features studied and that there was no negative interaction. The seedling vigor index was found to have a strong positive linear relationship $\left(r^{2}=0.861\right)$ with an $86 \%$ germination percentage, $\left(r^{2}=0.817\right)$ an $82 \%$ germination index, $\left(r^{2}=0.764\right)$ an $76 \%$ radicle length, $\left(r^{2}=0.802\right)$ an $80 \%$ seedling length, $\left(r^{2}=0.697\right)$ an $70 \%$ radicle fresh weight and $\left(r^{2}=0.671\right)$ an $67 \%$ radicle dry weight, respectively (Fig $1 \mathrm{~A}-\mathrm{E} ; \mathrm{G}$ ). When Fig $1 \mathrm{~F}$ and $\mathrm{H}$ are examined, it is determined that the seedling vigor index has a significant, weak positive correlation with

Table 2: The means and the Duncan groups of PFW, SFW, RDW, PDW, SDW and SVI properties of soybean variety (Gapsoy).

\begin{tabular}{|c|c|c|c|c|c|c|c|c|c|c|c|}
\hline $\begin{array}{l}\text { Germination } \\
\text { temperature }\left({ }^{\circ} \mathrm{C}\right)\end{array}$ & $\begin{array}{c}\text { Salt } \\
\text { doses (ppm) }\end{array}$ & $\begin{array}{l}\text { PFW } \\
(\mathrm{g})\end{array}$ & $* ; * *$ & $\begin{array}{l}\text { SFW } \\
(\mathrm{g})\end{array}$ & *;** & $\begin{array}{l}\mathrm{RDW}^{* * * *} \\
(\mathrm{~g})\end{array}$ & $\begin{array}{c}\text { PDW*;** } \\
(\mathrm{g})\end{array}$ & $\begin{array}{l}\text { SDW } \\
(g)\end{array}$ & $* ; * *$ & SVI & $* ; * *$ \\
\hline & SD1 & 560.8 & $a b$ & 587.2 & $a b$ & 4.4 ef & $94.0 \mathrm{a}-\mathrm{c}$ & 98.4 & $a-c$ & 294.4 & $\mathrm{de}$ \\
\hline & SD2 & 387.3 & gh & 411.2 & $\mathrm{f}$ & $5.2 \mathrm{~d}$ & $84.6 \mathrm{de}$ & 89.8 & $d-g$ & 270.3 & $d-f$ \\
\hline & SD3 & 487.3 & $c$ & 513.8 & c & $4.8 \mathrm{e}$ & $92.2 \mathrm{bc}$ & 97.0 & $\mathrm{bc}$ & 486.5 & $b$ \\
\hline & SD4 & 451.5 & $d$ & 478.1 & $d$ & $5.7 \quad b$ & $92.9 \mathrm{bc}$ & 98.6 & $a b$ & 362.2 & $c$ \\
\hline \multirow[t]{11}{*}{ GT1 } & SD5 & 562.3 & $a$ & 591.4 & $a$ & $7.4 \mathrm{a}$ & 99.9 a & 105.1 & $\mathrm{a}$ & 663.5 & $\mathrm{a}$ \\
\hline & SD6 & 532.5 & $b$ & 571.8 & $b$ & $5.2 \mathrm{~d}$ & $97.3 \mathrm{a}$ & 102.7 & a & 359.5 & $c$ \\
\hline & SD7 & 527.5 & $b$ & 561.9 & $b$ & $5.4 \mathrm{~cd}$ & $90.0 \mathrm{c}$ & 98.4 & $\mathrm{bc}$ & 302.1 & $d$ \\
\hline & SD8 & 436.8 & de & 472.8 & $d$ & $4.2 \mathrm{f}$ & $83.5 \mathrm{e}$ & 88.2 & $\mathrm{fg}$ & 163.2 & jk \\
\hline & SD9 & 454.4 & $d$ & 458.5 & de & $3.4 \mathrm{~h}$ & 81.5 e & 87.6 & $\mathrm{fg}$ & 145.9 & $\mathrm{k}$ \\
\hline & SD10 & 236.2 & j & 250.9 & $\mathrm{i}$ & $3.1 \mathrm{i}$ & $48.9 \mathrm{~g}$ & 52.0 & $\mathrm{i}$ & 115.6 & I \\
\hline & Average & 463.7 & A & 489.8 & A & $4.9 \mathrm{~A}$ & $86.5 \mathrm{~A}$ & 91.8 & A & 316.3 & A \\
\hline & SD1 & 462.8 & $\mathrm{~cd}$ & 485.0 & $\mathrm{~cd}$ & $3.8 \mathrm{~g}$ & $78.4 \mathrm{e}$ & 82.2 & $g$ & 168.5 & $\mathrm{i}-\mathrm{k}$ \\
\hline & SD2 & 422.1 & ef & 437.0 & ef & $3.2 \mathrm{hi}$ & $88.8 \mathrm{~cd}$ & 92.0 & $c-f$ & 226.0 & gh \\
\hline & SD3 & 434.6 & de & 457.2 & de & $4.4 \mathrm{f}$ & $84.5 \mathrm{de}$ & 88.9 & $e-g$ & 234.9 & $\mathrm{fg}$ \\
\hline & SD4 & 481.9 & $c$ & 511.2 & $c$ & $5.3 \mathrm{~d}$ & $92.7 \mathrm{bc}$ & 96.1 & $\mathrm{bc}$ & 653.3 & $\mathrm{a}$ \\
\hline \multirow[t]{7}{*}{ GT2 } & SD5 & 398.1 & $\mathrm{fg}$ & 422.2 & $f$ & $5.6 \mathrm{bc}$ & $87.4 \mathrm{~cd}$ & 96.4 & $\mathrm{bc}$ & 354.6 & $c$ \\
\hline & SD6 & 407.9 & $\mathrm{fg}$ & 422.8 & $f$ & $5.4 \mathrm{~cd}$ & $90.9 \mathrm{c}$ & 94.5 & $b-d$ & 251.6 & $e-g$ \\
\hline & SD7 & 397.2 & $\mathrm{fg}$ & 422.9 & $f$ & $3.4 \mathrm{~h}$ & $83.0 \mathrm{e}$ & 92.7 & $c-e$ & 194.4 & hi \\
\hline & SD8 & 363.5 & $\mathrm{~h}$ & 273.8 & $\mathrm{~h}$ & $2.4 \mathrm{k}$ & $95.1 \mathrm{ab}$ & 88.4 & $\mathrm{fg}$ & 172.7 & $\mathrm{ij}$ \\
\hline & SD9 & 262.8 & $\mathrm{i}$ & 370.4 & $g$ & $2.6 \mathrm{j}$ & $62.4 \mathrm{f}$ & 65.0 & $\mathrm{~h}$ & 59.8 & $\mathrm{~m}$ \\
\hline & SD10 & 236.5 & j & 247.6 & $\mathrm{i}$ & $1.8 \quad$ I & $50.2 \mathrm{~g}$ & 52.5 & $\mathrm{i}$ & 26.5 & $\mathrm{n}$ \\
\hline & Average & 386.7 & B & 405.0 & B & $3.8 \mathrm{~B}$ & 81.3 B & 84.9 & B & 234.2 & B \\
\hline \multicolumn{2}{|l|}{ LSD (0.05) for GT } & 7.160 & $* *$ & 7.039 & $* *$ & $0.078^{* *}$ & $1.428^{* *}$ & 1.466 & ** & 9.34 & ** \\
\hline \multicolumn{2}{|l|}{ LSD (0.05) for SD } & 16.010 & $* *$ & 15.741 & ** & 0.174 ** & $3.194 * *$ & 3.278 & $* *$ & 20.88 & ** \\
\hline \multicolumn{2}{|c|}{ LSD $(0.05)$ for $G T \times S D$} & 45.282 & ** & 44.521 & ** & 0.492 ** & $9.033 * *$ & 9.270 & ** & 59.06 & ** \\
\hline \multicolumn{2}{|l|}{ CV $(\%)$} & 3.765 & & 3.518 & & 4.021 & 3.806 & 3.710 & & 7.58 & \\
\hline
\end{tabular}

PFW: Plumule fresh weight, SFW: Seed fresh weight, RDW: Radicle dry weight, PDW: Plumule dry weight, SDW: Seed dry weight,

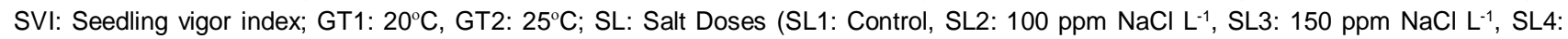
250 ppm NaCl L-1, SL5: 750 ppm NaCl L-1, SL6: 1000 ppm NaCl L-1, SL7: 2250 ppm NaCl L-1, SL8: 5000 ppm NaCl L-1, SL9: 7500 ppm $\mathrm{NaCl} \mathrm{L-1}$, SL10: 10000 ppm NaCl L-1)

*: The means in the same column, expressed in lowercase and indicated with different letters, are statistically different from each other within the $\mathrm{P}<0.05$ error limits according to LSD test.

${ }^{* *}$ : The means in the same column, expressed in the capital and indicated with different letters, are statistically different from each other within the $\mathrm{P}<0.05$ error limits according to LSD test. 

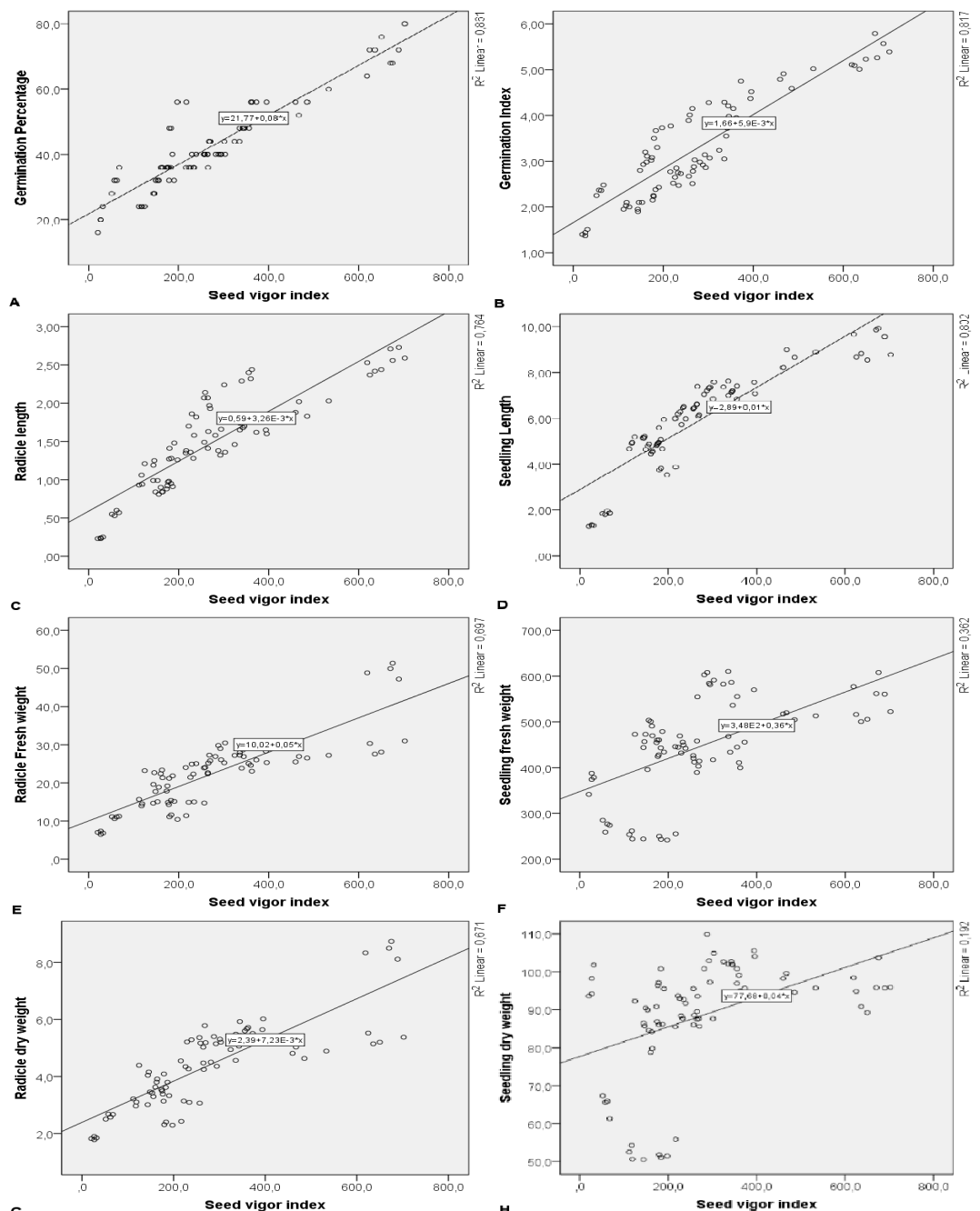

Fig 1: Simple scatter plot matrices between seedling vigor index and other studied properties.

seedling fresh weight and seedling dry weight. Thus, it is seen that the seedling vigor index has significant and positive linear relationships $\left(r^{2}=0.362\right.$ and $\left.r^{2}=0.192\right)$ with the seedling fresh weight and the seedling dry weight.

The study was confined to determine the effect of temperature and salinity levels on germination percentage, germination index, radicle length, plumule length, seedling length, radicle fresh weight, plumule fresh weight, radicle dry weight, plumule dry weight, seedling dry weight and seedling vigor index of Glycine max L. According to the findings of the research, the effects of salinity on all parameters of germination and seedling growth characteristics of soybean seeds were found to be statistically significant (Table 1 and 2). Analysis of variance showed that there were significant variations between germination temperatures and among the salt concentrations during the germination and seedling stages. And also, as shown in Table 1 and 2, it appears that the interaction effects of germination temperatures and salt concentrations on all the parameters studied showed statistically significant (\%5) differences. However, all observed parameters were positively affected by $\mathrm{NaCl}$ till SL5 (750 ppm NaCl L-1), but they were diminished by SL6 - SL10 NaCl concentrations (Table 1). As is known,

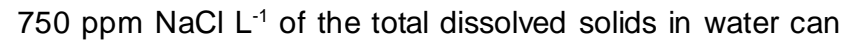
have detrimental effects on sensitive crops, but salinity tolerant or moderately tolerant crops may not be sensitive to this concentration. Soybean species tolerate the salinity to a specific level due to its moderately salt-tolerant properties and soybean yield decreases when the soil salinity exceeds this specific level (Ashraf and Wu, 1994) at all temperature regimes (Gulzar et al. 2001). When the results of the trials are examined from Table 1 and 2, it was determined that the effect of salt stress increases when the temperature level increases in all the properties examined and it was found that the highest values at $25^{\circ} \mathrm{C}$ were determined from the fourth salinity level. Thus, it was observed that the increase in temperature compared to $20^{\circ} \mathrm{C}$ reduced the tolerance of soybean plants to salt stress. In rare plant species, the change of necessary temperature has little effect on germination, while others are very sensitive to temperature regimes (Gulzar et al. 2001). The results showed that the response of germination percentage, 
germination index, radicle length, seedling length, and root fresh weight to salt stress under $25^{\circ} \mathrm{C}$ temperature conditions was severe than $20^{\circ} \mathrm{C}$. The radicle and seedling length are reported to be important features in salt stress sensitivity assessment (Jamil et al. 2006). Khan and Ungar (1997) reported that in the high-temperature regime, there was an interaction with the high salt concentration, which hinders germination. Similar results have been reported by many researchers (Gulzar et al. 2001). After a tolerated saline level, the decrease of growth in radicle and seedling can be related to $\mathrm{NaCl}$ toxicity and disproportion in nutrient absorption by seedlings. According to the results of some previous studies, salinity reduces water absorption and growth of radicle and seedling (Khan, 1998; Nedjimi, 2013). Salinity is reported to significantly reduce nutrient absorption and root growth rate (Gulzar et al. 2001).

\section{CONCLUSION}

The germination attributes of soybean varied between germination temperatures under salt stress in this experiment. The above results suggest that seeds of soybean can germinate well and rapidly at a lower level of salt $\left(\leq 750 \mathrm{ppm} \mathrm{NaCl} \mathrm{\textrm {L } ^ { - 1 } )}\right.$ under $20^{\circ} \mathrm{C}$ germination temperature, but the germination percentage of the seeds decreases at a higher level of salt $\left(10000 \mathrm{ppm} \mathrm{NaCl} \mathrm{L}^{-1}\right)$.

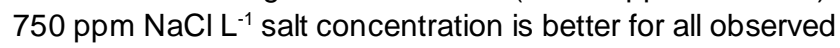
attributes at $20^{\circ} \mathrm{C}$. It was observed that the tolerance to salinity decreased as the germination temperatureincreased. Additionally, it has been shown that the soybean reacts differently to increased salinity concentrations under different temperatures. It is concluded that significant positive correlations were observed among observed properties of soybean variety under effects of salinity concentrations at different temperatures.

\section{REFERENCES}

Altuner, F., Oral, E., Ruveyde, T. and Baran, İ. (2020). The impact of salt $(\mathrm{NaCl})$ stress on germination characteristics of gibberellic acid (GA3) pretreated quinoa (Chenopodium quinoa Willd.) seed. KSU Journal of Agriculture and Nature. 23(2): 349-356.

Ashraf, M.Y. and Wu, L. (1994). Breeding for salinity tolerance in plants. Critical Reviews in Plant Sciences. 13(1): 17-42.

Chaitanya, K.V., Krishna, C., Ramana, G.V. and Beebi, S.K. (2014). Salinity stress and sustainable agriculture-A review. Agricultural Reviews. 35(1): 34-41.

Dutta, P. and Bera, A.K. (2014). Effect of nacl salinity on seed germination and seedling growth of mungbean cultivars. Legume Research-An International Journal. 37(2): 161-164.

Gulzar, S., Khan, M. and Ungar, I. (2001). Effect of salinity and temperature on the germination of Urochondra setulosa (Trin.) CE Hubbard. Seed Science and Technology. 29(1): 21-30.

Hosseini, M.K., Powell, A.A. and Bingham, I.J. (2002). Comparison of the seed germination and early seedling growth of soybean in saline conditions. Seed Science Research. 12(3): 165-172.
Jamil, M., Deog Bae, L., Kwang Yong, J., Ashraf, M., Sheong Chun, L. and Eui Shik, R. (2006). Effect of salt $(\mathrm{NaCl})$ stress on germination and early seedling growth of four vegetables species. Journal of Central European Agriculture. 7(2): 273-282.

Jamil, M. and Rha, E.S. (2004). The effect of salinity $(\mathrm{NaCl})$ on the germination and seedling of sugar beet (Beta vulgaris L.) and cabbage (Brassica oleracea L.). Plant Resources. 7(3): 226-232.

Karim, M.A., Utsunomiya, N. and Shigenaga, S. (1992). Effect of sodium chloride on germination and growth of hexaploid triticale at early seedling stage. Japanese Journal of Crop Science. 61(2): 279-284.

Khan, M. (1998). Germination of the salt tolerant shrub Suaeda fruticosa from Pakistan: Salinity and temperature responses. Seed Science and Technology. 26: 657-667.

Khan, M.A. and Ungar, I.A. (1997). Effects of light, salinity and thermoperiod on the seed germination of halophytes. Canadian Journal of Botany. 75(5): 835-841.

Khan, M.A., Ungar, I.A. and Showalter, A.M. (2000). The effect of salinity on the growth, water status, and ion content of a leaf succulent perennial halophyte, Suaeda fruticosa (L.) Forssk. Journal of Arid Environments. 45(1): 73-84.

Mahmood, T., Iqbal, N., Raza, H., Qasim, M. and Ashraf, M.Y. (2010). Growth modulation and ion partitioning in salt stressed sorghum (Sorghum bicolor L.) by exogenous supply of salicylic acid. Pakistan Journal of Botany. 42(5): 3047-3054.

Miladinov, Z., Maksimovic, I., Balesević-Tubic, S., Djukic, V., Canak, P., Miladinovic, J. and Djordjevic, V. (2020). Priming seed mitigates the effects of saline stress in soybean seedlings. Legume Research. 43(2): 263-267.

Moosavi, S.S., Alaei, Y. and Khanghah, A.M. (2014). The effects of water seed pre-treatment on soybean vegetative and reproductive traits. International Journal of Agriculture and Forestry. 4(3A): 12-17.

Nedjimi, B. (2013). Effect of salinity and temperature on germination of Lygeum spartum. Agricultural Research. 2(4): 340-345.

Oral, E., Altuner, F., Tunçtürk, R. and Tunçtürk, M. (2019). The impact of salt $(\mathrm{NaCl})$ stress on germination characteristics of gibberellic acid pretreated wheat (Triticum durum Desf) seeds. Applied Ecology and Environmental Research. 17(5): 12057-12071.

Phang, T.H., Shao, G. and Lam, H.M. (2008). Salt tolerance in soybean. Journal of Integrative Plant Biology. 50(10): 1196-1212.

Ramana, G.V., Padhy, S.P. and Chaitanya, K.V. (2012). Differential responses of four soybean (Glycine max L.) cultivars to salinity stress. Legume Research. 35(3): 185-193.

Rathi, P. and Madan, S. (2019). Effect of glass industry effluent on seed germination and biochemical parameters of Glycine max (Soyabean). Indian Journal of Agricultural Research, 53(4): 468-472.

Turhan, H. and Ayaz, C. (2004). Effect of salinity on seedling emergence and growth of sunflower (Helianthus annuus L.) cultivars. International Journal of Agriculture Biology. 6(1): 149-152.

Wang, D. and Shannon, M. (1999). Emergence and seedling growth of soybean cultivars and maturity groups under salinity. Plant Soil and Tillage Research. 214(1-2): 117-124. 